\title{
Response of Integrated Nutrient Management on Nutrient Uptake, Economics and Nutrient Status of Soil in Bold Seeded Summer Groundnut
}

\author{
F.G. Vala, P.M. Vaghasia*, K.P. Zala and N. Akhatar \\ Main Oilseeds Research Station, Junagadh Agricultural University, Junagadh, Gujarat, India \\ *Corresponding author
}

A B S T R A C T

\begin{tabular}{|l|}
\hline K e y w o r d s \\
Groundnut, INM, \\
$\begin{array}{l}\text { Nutrient content, } \\
\text { Uptake, Nutrient } \\
\text { status }\end{array}$ \\
\hline Article Info \\
\hline $\begin{array}{l}\text { Accepted: } \\
\text { 04 December } 2017 \\
\text { Available Online: } \\
\text { 10 January 2018 }\end{array}$ \\
\hline
\end{tabular}

An experiment was conducted during summer season of 2016 on clayey soil at College of Agriculture, Junagadh Agricultural University, Junagadh to study the "Integrated nutrient management in bold seeded summer groundnut (Arachis hypogaea L.)". The study comprised of ten treatments consisting of three different organic sources of nutrients and these organic sources were combined with 50 and75 per cent recommended dose of fertilizer. The results revealed that combined application of 75\% RDF(18.75-37.50-37.50$\left.15 \mathrm{~kg} \mathrm{~N}-\mathrm{P}_{2} \mathrm{O}_{5}-\mathrm{K}_{2} \mathrm{O}-\mathrm{S} \mathrm{ha}{ }^{-1}\right)+25 \% \mathrm{~N}$ through FYM $(1.25 \mathrm{t} / \mathrm{ha})+$ Biofertilizer (Rhizobium and PSM @ $10 \mathrm{ml} \mathrm{kg}^{-1}$ seed) recorded significantly higher pod and haulm yield with gross (Rs. $102200 \mathrm{ha}^{-1}$ ), net realizations (Rs. $56582 \mathrm{ha}^{-1}$ ), benefit: cost ratio (2.24) N, P, K and S content $(4.56,0.51,0.60,0.32 \%$ and $1.90,0.31,0.72,0.26 \%)$ and uptake $(105.92,11.80$, $13.93,7.36 \mathrm{~kg} \mathrm{ha}^{-1}$ and $58.64,9.44,36.12,8.09 \mathrm{~kg} \mathrm{ha}^{-1}$ ) in pod and haulm, respectively and post-harvest $\mathrm{N}, \mathrm{P}_{2} \mathrm{O}_{5}$ and $\mathrm{S}$ available status $\left(255.00,40.30 \mathrm{~kg} \mathrm{ha}^{-1}\right.$ and $30.63 \mathrm{mg} \mathrm{kg}^{-1}$, respectively) of soil which was closely followed by application of $75 \% \mathrm{RDF}+25 \% \mathrm{~N}$ through Vermicompost + Biofertilizer.

\section{Introduction}

Groundnut is an important oilseed crop of India, cultivated in various parts of the country. Among the various agronomic practices, nutrient management has an important role in maximizing the pod yield. Judicial use of fertilizers is necessary for increasing agricultural production and reduced environmental pollution because continuous use of chemical fertilizers has deleterious effects on soil which in turn cause decline in productivity. Groundnut is an exhaustive crop and removes large amount of macro and micronutrient. No single source of nutrient is capable at supplying plant nutrients in adequate amount and balanced proportion. Therefore, to maintain soil fertility and to supply plant nutrients in balanced proportion for optimum growth, yield and quality of crop in an integrated manner in a specific agro ecological situation is to practice integrated nutrient supply through the combined use of biological and organic sources of plant nutrients (Kachot et al., 2001).Groundnut farmers use very less organic fertilizer resulting in severe mineral nutrient deficiencies due to inadequate and imbalance 
use of nutrients is one of the major factors responsible for low yield in groundnut (Veermani and Subrahmaniyan, 2011). Confectionary groundnut is gaining more important in recent years in view of its export potential to earn the foreign exchange and also to pattern at groundnut utilization for oil purpose is gradually changed during the past decades. The food and confectionary use is on the rise. The present experiment was therefore undertaken in order to increase the productivity of bold seeded groundnut, quality, nutrient uptake and post-harvest nutrient status of soil through efficient use of resources like organic manure, inorganic fertilizer and biofertilizer.

\section{Materials and Methods}

A field experiment was conducted with groundnut variety GJG 31 at College of Agriculture, Junagadh Agricultural University, Junagadh during the summer season of 2016. The experiment was laid out in Randomized Blocks Design with three replications and ten treatments. The following treatments were imposed viz., $\mathrm{T}_{1}$ (control), $\mathrm{T}_{2}$ [Biofertilizer (Rhizobium and PSM)], $\mathrm{T}_{3}$ (FYM $5 \mathrm{t} \mathrm{ha}^{-1}$ ), $\mathrm{T}_{4}$ [100\% RDF (25-50-50-20 kg N-P $\mathrm{P}_{2} \mathrm{O} 5-\mathrm{K}_{2} \mathrm{O}-\mathrm{S}$ $\left.\left.\mathrm{ha}^{-1}\right)\right], \mathrm{T}_{5}(50 \% \mathrm{RDF}+50 \% \mathrm{~N}$ through FYM), $\mathrm{T}_{6}(50 \% \mathrm{RDF}+50 \% \mathrm{~N}$ through $\mathrm{FYM}$ + Biofertilizer $), \mathrm{T}_{7}(75 \% \mathrm{RDF}+$ Biofertilizer $)$, $\mathrm{T}_{8}(75 \% \mathrm{RDF}+25 \% \mathrm{~N}$ through $\mathrm{FYM}), \mathrm{T}_{9}$ $(75 \% \mathrm{RDF}+25 \% \mathrm{~N}$ through $\mathrm{FYM}+$ Biofertilizer) and $\mathrm{T}_{10}(75 \% \mathrm{RDF}+25 \% \mathrm{~N}$ through Vermicompost + Biofertilizer).The soil of the experimental plot was clayey in texture and slightly alkaline in reaction with $\mathrm{pH} 7.9$, EC $0.38 \mathrm{ds} \mathrm{m}^{-1}$ and organic carbon $0.62 \%$. The soil was low in available nitrogen $\left(241.00 \mathrm{~kg} \mathrm{ha}{ }^{-1}\right)$, medium in available phosphorus $\left(31.60 \mathrm{~kg} \mathrm{ha}^{-1}\right)$, potash $(215.36 \mathrm{~kg}$ $\mathrm{ha}^{-1}$ ) and sulphur (17.5 $\left.\mathrm{mg} \mathrm{kg}^{-1}\right)$. Groundnut was sown@125 kg seed/ha in rows $30 \mathrm{~cm}$ apart and $10 \mathrm{~cm}$ plant to plant spacing. The recommended dose of fertilizers @
25:50:50:20 kg NPKS ha ${ }^{-1}$ was considered as $100 \%$ RDF. The crop was fertilized as per treatments at the time of sowing, while well decomposed FYM containing $0.5 \% \mathrm{~N}, 0.2 \%$ $\mathrm{P}_{2} \mathrm{O}_{5}$, and $0.5 \% \quad \mathrm{~K}_{2} \mathrm{O}$ and vermicompost containing $1.5 \% \mathrm{~N}, 1.0 \% \mathrm{P}_{2} \mathrm{O}_{5}$ and $1.5 \% \mathrm{~K}_{2} \mathrm{O}$ were applied based on the nutrient equivalent basis of groundnut nitrogen requirement at preparation of soil. Seed was inoculated with a culture of Rhizobium plus PSM as per treatment before sowing. Other cultural operations were done as per recommendation and crop requirements. Regularly biometric observations were recorded at specific time intervals by selecting randomly five plants in each treatment. The initial and at harvest soil samples at $0-15 \mathrm{~cm}$ depth and organic manures were analyzed for different parameters by following standard methods (Jackson, 1974). Pod and haulm plant samples after harvest were analyzed for total N, P, K and S. Finally the crop was harvested and produce were dried, threshed, cleaned and weighed.

\section{Results and Discussion}

\section{Effect on content and uptake of nutrients}

The present study revealed that nitrogen, phosphorous, potassium and sulphur content (Table 1) and uptake by the crop (Table 2) was significantly influenced by integrated nutrient management treatments. Significantly higher $\mathrm{N}, \mathrm{P}, \mathrm{K}$ and $\mathrm{S}$ content in pod $(4.56,0.51,0.60$ and $0.32 \%$, respectively) and $\operatorname{haulm}(1.90 \%, 0.31 \%, 0.72 \%$ and $0.26 \%$, respectively) were noticed under the treatment $\mathrm{T}_{9}$ which constitutes $75 \% \mathrm{RDF}+25 \% \mathrm{~N}$ through FYM + Biofertilizer. However, it was found statistically at par with treatments $\mathrm{T}_{6}$, $\mathrm{T}_{10}$ and $\mathrm{T}_{2}$ in respect of $\mathrm{N}$ content, $\mathrm{T}_{6}, \mathrm{~T}_{10}$ and $\mathrm{T}_{7}$ in respect of $\mathrm{P}$ and $\mathrm{S}$ content and $\mathrm{T}_{8}, \mathrm{~T}_{10}$ and $T_{7}$ in respect of $K$ content in pod, while in haulm, it was found statistically comparable with treatments $\mathrm{T}_{10}, \mathrm{~T}_{6}$ and $\mathrm{T}_{3}$ in $\mathrm{N}$ content, $\mathrm{T}_{8}$, 
$\mathrm{T}_{7}, \mathrm{~T}_{6}$ and $\mathrm{T}_{10}$ in $\mathrm{P}$ content, $\mathrm{T}_{8}$ and $\mathrm{T}_{10}$ in $\mathrm{K}$ content and $\mathrm{T}_{8}$ in $\mathrm{S}$ content. An examination of data (Table 2) showed that different treatments exerted their signifiant influence on nutriments uptake by pod and haulm. Application of $75 \% \mathrm{RDF}+25 \% \mathrm{~N}$ through $\mathrm{FYM}+$ Biofertilizer $\left(\mathrm{T}_{9}\right)$ reported significantly the highest nitrogen uptake (105.92 and $58.64 \mathrm{~kg} \mathrm{ha}^{-1}$ ), phosphorus uptake (11.80 and $\left.9.44 \mathrm{~kg} \mathrm{ha}^{-1}\right)$, potash uptake (13.93 and $\left.22.19 \mathrm{~kg} \mathrm{ha}^{-1}\right)$ and sulphur uptake (7.36 and $8.09 \mathrm{~kg} \mathrm{ha}^{-1}$ ) by pod and haulm, respectively which was remained at par with treatments $\mathrm{T}_{6}$ and $\mathrm{T}_{10}$ in respect of $\mathrm{N}$ and $\mathrm{P}$, $\mathrm{T}_{8}, \mathrm{~T}_{10}, \mathrm{~T}_{6}, \mathrm{~T}_{5}, \mathrm{~T}_{4}$ and $\mathrm{T}_{7}$ in respect of $\mathrm{K}$ and $\mathrm{T}_{6}, \mathrm{~T}_{10}$ and $\mathrm{T}_{7}$ in respect of $\mathrm{S}$. Treatment $\mathrm{T}_{1}$ (control) recorded the lowest $\mathrm{N}$. P, K and $\mathrm{S}$ uptake by pod and haulm.

A glimpse of data (Table 2) indicated that significantly the highest total $\mathrm{N}, \mathrm{P}, \mathrm{K}$ and $\mathrm{S}$ uptake $\left(164.56,21.25,36.12\right.$ and $15.45 \mathrm{~kg} \mathrm{ha}^{-1}$, respectively) by crop were recorded in treatment $\mathrm{T}_{9}(75 \% \mathrm{RDF}+25 \% \mathrm{~N}$ through $\mathrm{FYM}+$ Biofertilizer) which was remained statistically at par with $\mathrm{T}_{10}$ and $\mathrm{T}_{6}$ in $\mathrm{N}$ uptake, $\mathrm{T}_{10}$ in $\mathrm{K}$ uptake and $\mathrm{T}_{6}$ in $\mathrm{S}$ uptake by crop. The combined application of chemical fertilizers along with enough bulk of FYM has always stimulated the uptake of nutrients and partly might by because of stimulated microbes flush and improved root growth due to congenial soil physical condition. Application of $\mathrm{N}$ fixing biofertilizers enhances the soil $\mathrm{N}$ and PSM produces the organic acids which may partly by responsible for quick release of nutrients which resulted into more content of nutrients. Thus, improvement in uptake of N, P, K and S might be attributed to their respective higher concentration in pod and haulm and associated with higher pod and haulm yields. The results of present investigation are in close agreements with the findings of Zalate and Padmani (2010), Tatpurkar et al., (2014) and Vallabh et al., (2015).

Table.1 Effect of different treatments on N, P, K and S content in pod and haulm of groundnut

\begin{tabular}{|c|c|c|c|c|c|c|c|c|c|}
\hline \multirow{3}{*}{\multicolumn{2}{|c|}{ Treatments }} & \multicolumn{8}{|c|}{ Nutrient content (\%) } \\
\hline & & \multicolumn{2}{|c|}{$\mathrm{N}$} & \multicolumn{2}{|c|}{ P } & \multicolumn{2}{|c|}{ K } & \multicolumn{2}{|c|}{$\mathrm{S}$} \\
\hline & & Pod & Haulm & Pod & Haulm & Pod & Haulm & Pod & Haulm \\
\hline$T_{1}$ & Control & 3.41 & 1.63 & 0.38 & 0.18 & 0.51 & 0.61 & 0.20 & 0.15 \\
\hline $\mathbf{T}_{2}$ & $\begin{array}{l}\text { Biofertilizer (Rhizobium and } \\
\text { PSM) }\end{array}$ & 3.99 & 1.65 & 0.43 & 0.21 & 0.53 & 0.65 & 0.23 & 0.16 \\
\hline $\mathbf{T}_{3}$ & FYM $\left(5 \mathrm{t} \mathrm{ha}^{-1}\right)$ & 3.86 & 1.73 & 0.42 & 0.25 & 0.54 & 0.64 & 0.26 & 0.21 \\
\hline $\mathbf{T}_{4}$ & $\begin{array}{l}100 \% \text { RDF }(25-50-50-20 \mathrm{~kg} \mathrm{~N}- \\
\left.\mathrm{P}_{2} \mathrm{O}_{5}-\mathrm{K}_{2} \mathrm{O}-\mathrm{S} \mathrm{ha}^{-1}\right)\end{array}$ & 3.59 & 1.67 & 0.41 & 0.24 & 0.52 & 0.62 & 0.24 & 0.19 \\
\hline $\mathbf{T}_{5}$ & $\begin{array}{l}50 \% \mathrm{RDF}+50 \% \mathrm{~N} \text { through } \\
\text { FYM }\end{array}$ & 3.80 & 1.71 & 0.43 & 0.23 & 0.55 & 0.63 & 0.25 & 0.21 \\
\hline $\mathrm{T}_{6}$ & $\begin{array}{l}50 \% \mathrm{RDF}+50 \% \mathrm{~N} \text { through } \\
\text { FYM + Biofertilizer }\end{array}$ & 4.23 & 1.85 & 0.49 & 0.20 & 0.58 & 0.66 & 0.30 & 0.24 \\
\hline$\overline{T_{7}}$ & 75\% RDF + Biofertilizer & 3.56 & 1.70 & 0.44 & 0.28 & 0.56 & 0.67 & 0.28 & 0.20 \\
\hline $\mathrm{T}_{8}$ & $\begin{array}{l}75 \% \mathrm{RDF}+25 \% \mathrm{~N} \text { through } \\
\text { FYM }\end{array}$ & 3.64 & 1.65 & 0.39 & 0.29 & 0.59 & 0.71 & 0.22 & 0.23 \\
\hline$\overline{T_{9}}$ & $\begin{array}{l}75 \% \mathrm{RDF}+25 \% \mathrm{~N} \text { through } \\
\text { FYM + Biofertilizer }\end{array}$ & 4.56 & 1.90 & 0.51 & 0.31 & 0.60 & 0.72 & 0.32 & 0.26 \\
\hline $\mathrm{T}_{10}$ & $\begin{array}{l}75 \% \mathrm{RDF}+25 \% \mathrm{~N} \text { through } \\
\text { vermicompost }+ \text { Biofertilizer }\end{array}$ & 4.04 & 1.87 & 0.45 & 0.26 & 0.57 & 0.69 & 0.29 & 0.18 \\
\hline & S.Em. \pm & 0.21 & 0.06 & 0.02 & 0.01 & 0.01 & 0.01 & 0.01 & 0.01 \\
\hline & C.D. $(P=0.05)$ & 0.64 & 0.18 & 0.07 & 0.05 & 0.04 & 0.04 & 0.05 & 0.04 \\
\hline & C. V. \% & 9.76 & 6.08 & 9.66 & 12.21 & 4.90 & 4.05 & 11.84 & 13.79 \\
\hline
\end{tabular}


Table.2 Effect of different treatments on uptake of N, P, K and S by groundnut

\begin{tabular}{|c|c|c|c|c|c|c|c|c|c|c|c|c|c|}
\hline \multirow{3}{*}{\multicolumn{2}{|c|}{ Treatments }} & \multicolumn{12}{|c|}{ Nutrient uptake(kg ha $\left.{ }^{-1}\right)$} \\
\hline & & \multicolumn{3}{|c|}{$\mathrm{N}$} & \multicolumn{3}{|c|}{$\mathrm{P}$} & \multicolumn{3}{|c|}{$\mathrm{K}$} & \multicolumn{3}{|c|}{ S } \\
\hline & & Pod & Haulm & Total & Pod & Haulm & Total & Pod & Haulm & Total & Pod & Haulm & Total \\
\hline $\mathbf{T}_{1}$ & Control & 59.00 & 38.36 & 97.36 & 6.48 & 4.33 & 10.81 & 8.82 & 14.53 & 23.36 & 3.48 & 3.46 & 6.94 \\
\hline $\mathbf{T}_{2}$ & $\begin{array}{l}\text { Biofertilizer (Rhizobium } \\
\text { and PSM) }\end{array}$ & 72.25 & 41.94 & 114.19 & 7.75 & 5.48 & 13.23 & 9.66 & 16.38 & 26.04 & 4.20 & 4.17 & 8.36 \\
\hline $\mathbf{T}_{\mathbf{3}}$ & FYM $\left(5 \mathrm{t} \mathrm{ha}^{-1}\right)$ & 76.79 & 43.08 & 119.87 & 8.45 & 6.22 & 14.67 & 10.81 & 15.92 & 26.73 & 5.20 & 5.30 & 10.50 \\
\hline $\mathbf{T}_{4}$ & $\begin{array}{l}100 \% \text { RDF (25-50-50-20 } \\
\left.\mathrm{kg} \mathrm{N}-\mathrm{P}_{2} \mathrm{O}_{5}-\mathrm{K}_{2} \mathrm{O}-\mathrm{S} \mathrm{ha}^{-1}\right)\end{array}$ & 80.16 & 41.40 & 121.56 & 9.18 & 5.84 & 15.02 & 11.75 & 15.47 & 27.22 & 5.56 & 4.66 & 10.22 \\
\hline $\mathbf{T}_{\mathbf{5}}$ & $\begin{array}{l}50 \% \mathrm{RDF}+50 \% \mathrm{~N} \\
\text { through FYM }\end{array}$ & 83.97 & 44.46 & 128.43 & 9.40 & 5.99 & 15.39 & 12.15 & 16.49 & 28.64 & 5.42 & 5.46 & 10.88 \\
\hline $\mathrm{T}_{6}$ & $\begin{array}{l}50 \% \mathrm{RDF}+50 \% \mathrm{~N} \\
\text { through FYM }+ \\
\text { Biofertilizer }\end{array}$ & 93.09 & 53.39 & 146.46 & 10.71 & 5.77 & 16.47 & 12.80 & 19.03 & 31.82 & 6.60 & 6.82 & 13.44 \\
\hline $\mathrm{T}_{7}$ & $75 \%$ RDF + Biofertilizer & 75.02 & 42.44 & 117.46 & 9.36 & 7.09 & 16.45 & 11.74 & 16.82 & 28.56 & 5.82 & 5.00 & 10.83 \\
\hline $\mathbf{T}_{8}$ & $\begin{array}{l}75 \% \mathrm{RDF}+25 \% \mathrm{~N} \\
\text { through FYM }\end{array}$ & 82.64 & 37.62 & 120.26 & 9.03 & 6.58 & 15.60 & 13.39 & 16.19 & 29.58 & 5.08 & 5.27 & 10.36 \\
\hline $\mathrm{T}_{9}$ & $\begin{array}{l}75 \% \mathrm{RDF}+25 \% \mathrm{~N} \\
\text { through FYM }+ \\
\text { Biofertilizer }\end{array}$ & 105.92 & 58.64 & 164.56 & 11.80 & 9.44 & 21.25 & 13.93 & 22.19 & 36.12 & 7.36 & 8.09 & 15.45 \\
\hline $\mathrm{T}_{10}$ & $\begin{array}{l}75 \% \mathrm{RDF}+25 \% \mathrm{~N} \\
\text { through vermicompost }+ \\
\text { Biofertilizer }\end{array}$ & 91.99 & 54.23 & 146.22 & 10.17 & 7.59 & 17.76 & 13.17 & 19.95 & 33.13 & 6.46 & 5.12 & 11.58 \\
\hline & S.Em. \pm & 5.75 & 5.56 & 6.40 & 0.68 & 0.64 & 1.06 & 0.84 & 1.13 & 1.26 & 0.58 & 0.45 & 0.74 \\
\hline & C.D. $(\mathrm{P}=0.05)$ & 17.08 & 7.62 & 19.02 & 2.02 & 1.92 & 3.16 & 2.51 & 3.36 & 3.76 & 1.73 & 1.36 & 2.20 \\
\hline & C. V. \% & 12.14 & 9.76 & 8.69 & 12.76 & 17.44 & 11.77 & 12.41 & 11.35 & 7.54 & 18.29 & 14.90 & 11.82 \\
\hline
\end{tabular}


Table.3 Effect of different treatments on yield and economics

\begin{tabular}{|c|c|c|c|c|c|c|c|}
\hline \multicolumn{2}{|c|}{ Treatments } & \multirow{2}{*}{$\begin{array}{c}\begin{array}{c}\text { Pod } \\
\text { yield } \\
\left(\mathrm{kg} \mathrm{ha}^{-1}\right)\end{array} \\
1714\end{array}$} & \multirow{2}{*}{$\begin{array}{c}\begin{array}{c}\text { Haulm } \\
\text { yield } \\
\left(\mathrm{kg} \mathrm{ha}^{-1}\right)\end{array} \\
2368\end{array}$} & \multirow{2}{*}{$\begin{array}{c}\text { Gross } \\
\text { return } \\
\text { (Rs. ha }^{-1} \text { ) } \\
75664\end{array}$} & \multirow{2}{*}{$\begin{array}{c}\begin{array}{c}\text { Cost of } \\
\text { cultivation } \\
\left.\text { (Rs. ha }^{-1}\right)\end{array} \\
38208\end{array}$} & \multirow{2}{*}{ 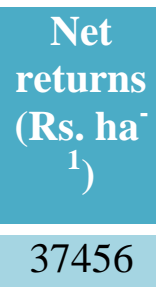 } & \multirow{2}{*}{$\begin{array}{c}\text { Benefit } \\
\text { cost } \\
\text { ratio } \\
1.98\end{array}$} \\
\hline$T_{1}$ & Control & & & & & & \\
\hline$\overline{T_{2}}$ & $\begin{array}{l}\text { Biofertilizer (Rhizobium and } \\
\text { PSM) }\end{array}$ & 1811 & 2536 & 80048 & 38796 & 41252 & 2.06 \\
\hline$\overline{T_{3}}$ & FYM $\left(5 \mathrm{tha}^{-1}\right)$ & 1991 & 2496 & 87128 & 43358 & 43770 & 2.01 \\
\hline$\overline{T_{4}}$ & $\begin{array}{l}100 \% \text { RDF }(25-50-50-20 \mathrm{~kg} \\
\left.\mathrm{N}-\mathrm{P}_{2} \mathrm{O}_{5}-\mathrm{K}_{2} \mathrm{O}-\mathrm{S} \mathrm{ha}^{-1}\right)\end{array}$ & 2256 & 2481 & 97683 & 45587 & 52096 & 2.14 \\
\hline $\mathrm{T}_{5}$ & $\begin{array}{l}50 \% \mathrm{RDF}+50 \% \mathrm{~N} \text { through } \\
\mathrm{FYM}\end{array}$ & 2201 & 2617 & 95891 & 44473 & 51419 & 2.16 \\
\hline $\mathrm{T}_{6}$ & $\begin{array}{l}50 \% \mathrm{RDF}+50 \% \mathrm{~N} \text { through } \\
\text { FYM + Biofertilizer }\end{array}$ & 2200 & 2882 & 96646 & 45061 & 51586 & 2.14 \\
\hline$\overline{T_{7}}$ & 75\% RDF + Biofertilizer & 2114 & 2506 & 92078 & 44330 & 47748 & 2.08 \\
\hline$\overline{T_{8}}$ & $\begin{array}{l}75 \% \mathrm{RDF}+25 \% \mathrm{~N} \text { through } \\
\text { FYM }\end{array}$ & 2278 & 2276 & 97948 & 45030 & 52918 & 2.18 \\
\hline$\overline{T_{9}}$ & $\begin{array}{l}75 \% \mathrm{RDF}+25 \% \mathrm{~N} \text { through } \\
\text { FYM + Biofertilizer }\end{array}$ & 2324 & 3080 & 102200 & 45618 & 56582 & 2.24 \\
\hline $\mathrm{T}_{10}$ & $\begin{array}{l}75 \% \mathrm{RDF}+25 \% \mathrm{~N} \text { through } \\
\text { vermicompost + Biofertilizer }\end{array}$ & 2274 & 2908 & 99684 & 46098 & 53586 & 2.16 \\
\hline & S.Em. \pm & 116 & 157 & - & - & - & - \\
\hline & C.D. $(P=0.05)$ & 344 & 469 & - & - & - & - \\
\hline & C. V. \% & 9.50 & 10.46 & - & - & - & - \\
\hline
\end{tabular}

Market price

\begin{tabular}{|l|l|l|l|}
\hline Commodity & Rs. $\mathrm{kg}^{-1}$ & Herbicide & Rs. $\mathrm{L}^{-1}$ \\
\hline Urea & 06.28 & Pendimethalin & 350.00 \\
\hline DAP & 25.00 & & \\
\hline MOP & 17.64 & Insecticide & Rs. L \\
\hline Cosavate & 132.00 & Imidacloprid & 560.00 \\
\hline FYM & 01.00 & Chloropyriphos & 270.00 \\
\hline Vermicompost & 04.00 & & \\
\hline Pod & 40.00 & & \\
\hline Haulm & 03.00 & & \\
\hline
\end{tabular}


Table.4 Effect of different treatments on post-harvest nutrient status in soil

\begin{tabular}{|c|c|c|c|c|c|c|}
\hline \multicolumn{2}{|c|}{ Treatments } & \multicolumn{5}{|c|}{ Post-harvest available nutrients in soil } \\
\hline & & \multicolumn{3}{|c|}{$\mathrm{kg} \mathrm{ha}^{-1}$} & \multirow{3}{*}{$\begin{array}{c}\mathbf{m g ~ k g}^{-1} \\
\mathbf{S} \\
17.03\end{array}$} & \multirow{3}{*}{$\begin{array}{c}\% \\
\text { O.C. } \\
0.62\end{array}$} \\
\hline & & $\mathbf{N}$ & $\mathbf{P}_{2} \mathbf{O}_{5}$ & $\mathrm{~K}_{2} \mathrm{O}$ & & \\
\hline$T_{1}$ & Control & 199.67 & 26.70 & 213.47 & & \\
\hline$T_{2}$ & Biofertilizer (Rhizobium and PSM) & 234.33 & 29.13 & 220.00 & 24.43 & 0.64 \\
\hline$T_{3}$ & FYM $\left(5 \mathrm{t} \mathrm{ha}^{-1}\right)$ & 240.67 & 30.87 & 223.33 & 22.20 & 0.66 \\
\hline $\mathbf{T}_{4}$ & $\begin{array}{l}100 \% \text { RDF }(25-50-50-20 \mathrm{~kg} \\
\left.\mathrm{N}-\mathrm{P}_{2} \mathrm{O}_{5}-\mathrm{K}_{2} \mathrm{O}-\mathrm{S} \mathrm{ha}^{-1}\right)\end{array}$ & 205.00 & 30.00 & 226.83 & 19.60 & 0.63 \\
\hline$T_{5}$ & $50 \% \mathrm{RDF}+50 \% \mathrm{~N}$ through FYM & 217.00 & 31.83 & 223.70 & 26.30 & 0.68 \\
\hline $\mathrm{T}_{6}$ & $\begin{array}{l}50 \% \text { RDF }+50 \% \mathrm{~N} \text { through FYM + } \\
\text { Biofertilizer }\end{array}$ & 225.00 & 34.57 & 229.00 & 27.13 & 0.69 \\
\hline $\mathbf{T}_{7}$ & 75\% RDF + Biofertilizer & 235.67 & 34.03 & 225.00 & 23.90 & 0.65 \\
\hline $\mathrm{T}_{8}$ & $75 \%$ RDF $+25 \% \mathrm{~N}$ through FYM & 246.67 & 35.37 & 228.00 & 28.67 & 0.67 \\
\hline $\mathbf{T}_{9}$ & $\begin{array}{l}75 \% \mathrm{RDF}+25 \% \mathrm{~N} \text { through FYM + } \\
\text { Biofertilizer }\end{array}$ & 255.00 & 40.30 & 232.00 & 30.63 & 0.72 \\
\hline$T_{10}$ & $\begin{array}{l}75 \% \mathrm{RDF}+25 \% \mathrm{~N} \text { through } \\
\text { vermicompost + Biofertilizer }\end{array}$ & 253.33 & 37.50 & 226.67 & 27.20 & 0.70 \\
\hline & S.Em. \pm & 9.68 & 1.56 & 6.51 & 1.62 & 0.03 \\
\hline & C.D. $(P=0.05)$ & 28.77 & 4.65 & NS & 4.82 & NS \\
\hline & C. V. \% & 7.25 & 8.20 & 5.04 & 11.33 & 8.04 \\
\hline
\end{tabular}

\section{Effect on economics}

Economics of the treatments revealed (Table 3) that the gross (Rs.102200 $\mathrm{ha}^{-1}$ ), net realizations (Rs. $56582 \mathrm{ha}^{-1}$ ) and benefit: cost ratio (2.24) were higher with combined application of $75 \%$ $\mathrm{RDF}+25 \% \mathrm{~N}$ through FYM + Biofertilizer $\left(\mathrm{T}_{9}\right)$ followed by $\mathrm{T}_{10}(75 \% \mathrm{RDF}+25 \% \mathrm{~N}$ through vermicompost + Biofertilizer) and $\mathrm{T}_{8}(75 \%$ $\mathrm{RDF}+25 \% \mathrm{~N}$ through FYM). The lower gross returns (Rs. $175664 \mathrm{ha}^{-1}$ ), net returns (Rs. 37456 $\mathrm{ha}^{-1}$ ) and $\mathrm{B}$ : C ratio (1.98) were noticed with the treatment $\mathrm{T}_{1}$ (control).

The higher gross realization, net realization and B: C ratio in $T_{9}, T_{10}$ and $T_{8}$ treatments might be due to the higher pod and haulm yields in these treatments. These findings are in vicinity with those reported by Gunri and Nath (2012) and Kumar et al., (2013).

\section{Effect on post-harvest nutrient status in soil}

The post-harvest status of available $\mathrm{N}, \mathrm{P}_{2} \mathrm{O}_{5}$ and $\mathrm{S}\left(255.00,40.30,30.63 \mathrm{~kg} \mathrm{ha}^{-1}\right.$, respectively) in the soil (Table 4) was significantly improved by application of $75 \% \mathrm{RDF}+25 \% \mathrm{~N}$ through FYM + Biofertilizer $\left(\mathrm{T}_{9}\right)$ over $\left(\mathrm{T}_{1}\right)$ control, but it was remained at par with $T_{10}, T_{8}, T_{3}, T_{7}$ and $T_{2}$ in available $\mathrm{N}$ status of soil, $\mathrm{T}_{10}$ in available $\mathrm{P}_{2} \mathrm{O}_{5}$ of soil and $\mathrm{T}_{8}, \mathrm{~T}_{10}, \mathrm{~T}_{6}$ and $\mathrm{T}_{5}$ in available $\mathrm{S}$ status of soil.

However, available $\mathrm{K}_{2} \mathrm{O}$ status of soil and organic carbon remained unaffected due to various treatments. The lower values of these parameters were observed under control $\left(\mathrm{T}_{1}\right)$. Available potassium status of soil remained unaffected might be due to medium level of potassium available in soil, however slight increased $\mathrm{K}_{2} \mathrm{O}$ level was observed under 
integrated approach. Available nitrogen, phosphorus and sulphur status in soil after harvest of groundnut crop were significantly increased due to addition of these nutrients through the application of FYM, chemical fertilizers and biofertilizers.

Addition to this carbon dioxide and organic acids released during the process of decomposition FYM which increase the availability of nutrients from native as well as applied fertilizers. Rhizobium fixed the atmospheric nitrogen and phosphobacteria solubilized the fixed phosphate by secretion of organic acids and phosphate enzymes. These all might have contributed towards increased available status of soil with respect to these nutrients.

The results of present investigation strongly support the findings of Choudhary et al., (2011) and Vallabh et al., (2015).

Based on field experimentation, it can be concluded that an integrated supply of farm yard manure, biofertilizers or vermicompost with chemical fertilizers in bold seeded summer groundnut favored for better nutrient uptake resulting in higher yield which has caused for higher net returns and $\mathrm{B}$ : $\mathrm{C}$ ratio and improved post-harvest nutrients soil status of crop.

\section{References}

Choudhary, S. K., Jat, M. K., Sharma, S.R. and Singh, P. 2011. Effect of INM on soil nutrient and yield in groundnut field of semi-arid area of Rajasthan. Legume Research, 34(4): 283 - 287.

Gunri, S.K. and Nath, R. 2012. Effect of organic manures, bio-fertilizers and biopesticides on productivity of summer groundnut (Arachis hypogaea L.) in red and laterite zone of West Bengal. Legume Research, 35(2): 144-148.

Jackson, M. L. 1974. Soil Chemical Analysis, Printice Hall India Pvt. Ltd. New Delhi. 327-350.

Kachot, N.A., Malavia, D.D., Solanki, R.M. and Sagarka, B.K. 2001. Integrated nutrient management in rainy season groundnut (Arachis hypogeaL). Indian Journal of Agronomy, 46 (3): 516-522.

Kumar, Y., Saxena, R., Gupta, K. C. and Fageria, V. D. 2013. Yield and Yield Attributes of Groundnut (Arachis hypogaea L.) as Influenced by Organic Practices in Semi-Arid Region. International Journal of Agriculture, Environment and Biotechnology, 6(4): 605-610.

Tatpurkar, Sheetal, G., Pushpa, V. V. and Barange. 2014. Effect of integrated nutrient management on yield, quality, nutrient content and uptake of groundnut in shrink-swell soil. International Journal of Agricultural Sciences, 10(1): 291-293.

Vallabh, N. C. and Brigendra, S. R. 2015. Performance evaluation of vermicompost on yield of Kharif groundnut and cotton crops. International Journal Forestry and Crop Improvement, 6(2): 127-131.

Veeramani, P. and Subrahmaniyan, K. 2011. Nutrient management for sustainable groundnut productivity in India - a review. International Journal of Engineering Science and Technology, 3:8138-8153

Zalate, P. Y. and Padmani, D.R. 2010. Effect of organic manure and biofertilizers on nutrient uptake pattern of groundnut (Arachis hypogaea L.).Ecology, Environment and Conservation Paper, 16(4): 501-504.

\section{How to cite this article:}

Vala, F.G., P.M. Vaghasia, K.P. Zala and Akhatar, N. 2018. Response of Integrated Nutrient Management on Nutrient Uptake, Economics and Nutrient Status of Soil in Bold Seeded Summer Groundnut. Int.J.Curr.Microbiol.App.Sci. 7(01): 174-180. doi: https://doi.org/10.20546/ijcmas.2018.701.019 